\title{
Upregulation of liver inducible nitric oxide synthase following thyroid hormone preconditioning: suppression by $\mathrm{N}$-acetylcysteine
}

\author{
VIRGINIA FERNÁNDEZ*1, GLADYS TAPIA ${ }^{1}$, PATRICIA VARELA ${ }^{1}$, \\ PAMELA CORNEJO ${ }^{1,2}$ and LUIS A. VIDELA ${ }^{1}$
}

\author{
${ }^{1}$ Programa de Farmacología Molecular y Clínica, Instituto de Ciencias Biomédicas, Facultad de Medicina, \\ Universidad de Chile, and ${ }^{2}$ Facultad de Ciencias de la Salud, Universidad Diego Portales, Santiago, Chile
}

\begin{abstract}
3,3,5-L-Triiodothyronine ( $\mathrm{T}_{3}$ ) exerts significant protection against ischemia-reperfusion (IR) liver injury in rats. Considering that the underlying mechanisms are unknown, the aim of this study was to assess the involvement of inducible nitric oxide synthase (iNOS) expression and oxidative stress in $\mathrm{T}_{3}$ preconditioning (PC). Male Sprague-Dawley rats given a single dose of $0.1 \mathrm{mg}$ of $\mathrm{T}_{3} / \mathrm{kg}$ were subjected to 1 -hour ischemia followed by 20 hours reperfusion, in groups of animals pretreated with $0.5 \mathrm{~g}$ of $\mathrm{N}$-acetylcysteine (NAC) $/ \mathrm{kg}$ 0.5 -hour prior to $\mathrm{T}_{3}$ or with the respective control vehicles. At the end of the reperfusion period, liver samples were taken for analysis of iNOS mRNA levels (RT-PCR), liver NOS activity, and hepatic histology. $\mathrm{T}_{3}$ protected against hepatic IR injury, with $119 \%$ enhancement in liver iNOS mRNA/18S rRNA ratios $(p<0.05)$ and 12.7-fold increase $(p<0.05)$ in NOS activity in $\mathrm{T}_{3}$-treated animals subjected to IR over values in controlsham operated rats, with a net 7.7-fold enhancement $(p<0.05)$ in the net effect of $\mathrm{T}_{3}$ on liver iNOS expression and a net enhancement of 0.58 units in NOS activity, changes that were abolished by NAC treatment before $\mathrm{T}_{3}$. It is concluded that $\mathrm{T}_{3}$-induced liver $\mathrm{PC}$ is associated with upregulation of iNOS expression as a protective mechanisms against IR injury, which is achieved through development of transient and reversible oxidative stress.
\end{abstract}

Key terms: thyroid hormone; oxidative stress; inducible nitric oxide synthase; liver preconditioning; ischemia-reperfusion injury; $\mathrm{N}$-acetylcysteine.

\section{INTRODUCTION}

Preconditioning (PC) is a phenomenon whereby protective strategies render organs resistant to subsequent damaging stimuli such as ischemia-reperfusion (IR), which in liver is of particular importance after tissue resections, transplantation, and hemorrhagic shock (Jaeschke, 2003). PC strategies include surgical interventions, gene therapy, and the use of pharmacological agents that can either inhibit injury mechanisms or induce a low level of stress initiating cellular defense pathways (Selzner et al., 2003; Casillas-Ramirez et al., 2006). In the latter case, however, pharmacological liver PC has not gained access to clinical application, possibly due to the appearance of drug side effects and/ or the attainment of unsuitable drug levels to achieve protection (Selzner et al., 2003; Casillas-Ramirez et al., 2006). For these reasons, new potential protective strategies showing effective results against liver IR injury have been studied in experimental animals, including the administration of L3,3,5-triiodothyronine $\left(\mathrm{T}_{3}\right)$ prior to an IR protocol (Fernandez et al., 2007a).

$\mathrm{T}_{3}$-induced liver $\mathrm{PC}$ is based on the development of a temporary and reversible increase in the oxidative stress status of the liver within a time period of 48 hours

\footnotetext{
* Corresponding author: Prof. Virginia Fernández, Programa de Farmacología Molecular y Clínica, Instituto de Ciencias Biomédicas, Facultad de Medicina, Universidad de Chile. E-mail: vfernand@med.uchile.cl, telephone: 56-2-9786256, fax: 56-2-7372783.
}

Received: March 24, 2009. In Revised form: August 25, 2009. Accepted: September 9, 2009. 
(Fernández et al., 2007a). Liver oxidative stress induced by $\mathrm{T}_{3}$ results from acceleration of energy metabolism and secondary oxidative processes leading to reactive oxygen species (ROS) generation and antioxidant depletion, both at the hepatocyte and Kupffer-cell levels (Videla et al., 2007). Under these conditions, reprogramming of gene expression through activation of specific redox-sensitive transcription factors may occur (Varela et al., 2006), leading to upregulation of the expression of proteins associated with cell protection and survival (Droge, 2002; Janssen-Heininger et al., 2008). Redox regulation of gene transcription by $\mathrm{T}_{3}$ represents an additional non-genomic mechanism of hormone action to those proposed for stimulation of plasma membrane transport, enzyme activities, mitochondrial respiration, and signal transduction cascades (Videla et al., 2007; Davis et al., 2008). This pathway involves (i) the redox activation of nuclear factor$\kappa \mathrm{B}(\mathrm{NF}-\kappa \mathrm{B})$, signal transducer and activator of transcription-3 (STAT3), and activator protein-1 (AP-1) (Fernandez et al., 2005a; Tapia et al., 2006; Fernandez et al., 2007b); (ii) upregulation of Kupffercell-dependent expression of the cytokines tumor necrosis factor- $\alpha$ (TNF- $\alpha$ ) and interleukin (IL)-1 and IL-6 (Tapia et al., 2003; 2006); and (iii) enhancement in the expression of anti-apoptotic proteins, acute-phase proteins, and enzymes, in addition to hepatocyte proliferation (Varela et al., 2006; Videla et al., 2007), which can afford cell protection.

In addition to the higher ROS production elicited by $\mathrm{T}_{3}$ treatment, liver nitric oxide ('NO) generation is also enhanced, an effect that is reversed toward control values after three days of $\mathrm{T}_{3}$ withdrawal (Fernandez et al., 1997). This effect of $\mathrm{T}_{3}$ is associated with a higher expression of inducible $\mathrm{NO}$ synthase (iNOS) through a cascade involving TNF- $\alpha$ release and activation of inhibitor of $\kappa \mathrm{B}(\mathrm{I} \kappa \mathrm{B})$ kinase (IKK) and NF$\kappa \mathrm{B}$ (Fernandez et al., 2005a), which exert prominent transcriptional control over expression of the iNOS gene in Kupffer cells, endothelial cells, and hepatocytes (Tsukamoto and Lin, 1997). The objective of this study was to test the hypothesis that iNOS is upregulated in $\mathrm{T}_{3}$-induced liver PC through a mechanism triggered by the oxidative stress underlying $\mathrm{T}_{3}$ calorigenesis. For this purpose, hepatic iNOS mRNA expression, liver NOS activity, and liver PC induced by $\mathrm{T}_{3}$ were assessed in a model of partial hepatic IR injury in the rat, either without or with pretreatment with $\mathrm{N}$-acetylcysteine (NAC), and results were analyzed according to histological evaluation.

\section{MATERIALS AND METHODS}

\section{Animals and treatments}

Male Sprague-Dawley rats (Animal facility of the Institute of Biomedical Sciences, Faculty of Medicine, University of Chile) weighing 180-200 g were housed on a 12-hour light/dark cycle and were provided with rat chow and water ad libitum. Animals received a single intraperitoneal dose of $0.1 \mathrm{mg}$ of $\mathrm{T}_{3} / \mathrm{kg}$ body weight or equivalent volumes of hormone vehicle $(0.1 \mathrm{~N} \mathrm{NaOH}$, controls $)$ at time zero (Fig. 1). At 48 hours after hormone treatment, rats were anesthetized with intraperitoneal $(1 \mathrm{~mL} / \mathrm{kg})$ zolazepam chlorhydrate $(25 \mathrm{mg} / \mathrm{mL})$ and tiletamine chlorhydrate $(25 \mathrm{mg} / \mathrm{mL})$ (Zoletil 50; Virbac S/A, Carros, France), and IR was induced by temporarily occluding the blood supply to the left and median lobes of the liver by means of a Schwartz clip (Fine Science Tools Inc., Vancouver, British Columbia, Canada) for 1 hour followed by 20 hours of reperfusion, as previously described (Fernandez et al., 2007a). Control animals were subjected to anesthesia and sham laparotomy. Studies with NAC were carried out with the groups described above receiving either $0.5 \mathrm{~g} / \mathrm{kg}$ of NAC or saline 0.5 hour before $\mathrm{T}_{3}$ administration, thus making up eight experimental groups (Fig. 1). At the end of the reperfusion period (Fig. 1), liver samples taken from the medial lobes were frozen in liquid nitrogen (assessment of iNOS mRNA) or fixed in phosphatebuffered formalin, embedded in paraffin, 
and stained with hematoxylin-eosin (morphology assessment) (Fernandez et al., 2007a). In separated groups of animals, liver samples were obtained after in situ perfusion with cold $150 \mathrm{mM} \mathrm{KCl}, 5$ $\mathrm{mM}$ Tris, $\mathrm{pH} 7.4$ buffer, in order to remove blood, followed by homogenization on ice and centrifugation at $100,000 \mathrm{~g}$ for $1 \mathrm{~h}$ at $4^{\circ} \mathrm{C}$, as previously described (Fernández et al., 1997). NOS activity was assayed by monitoring oxyhemoglobin to methemoglobin oxidation by $\mathrm{NO}$ at $401 \mathrm{~nm}$ versus $411 \mathrm{~nm}$ (Knowles et al., 1990). NOS activity was calculated by using the absorption coefficient of methemoglobin $\left(38,600 \mathrm{M}^{-1}\right.$ $\mathrm{cm}^{-1}$ ) for the wavelength pair 401 minus 411. Results were expressed as nmol NO/ $\mathrm{mg}$ protein/min (Knowles et al., 1990; Fernández et al., 1997) after protein assessment according to Lowry (1951). Experimental animal protocols and animal procedures complied with the Guide for the Care and Use of Laboratory Animals (National Academy of Sciences, NIH Publication 86-23, revised 1985).

Isolation of hepatic $R N A$ and reverse transcription-polymerase chain reaction (RT-PCR) assay for iNOS $m R N A$

Total liver RNA was extracted with TRIzol reagent (Invitrogen Corp., Carlsbad, CA, USA) (Chomczynski and Sacchi, 1987) and quantified by measurement of ultraviolet absorption at $260 \mathrm{~nm}$. For RT-PCR assay of

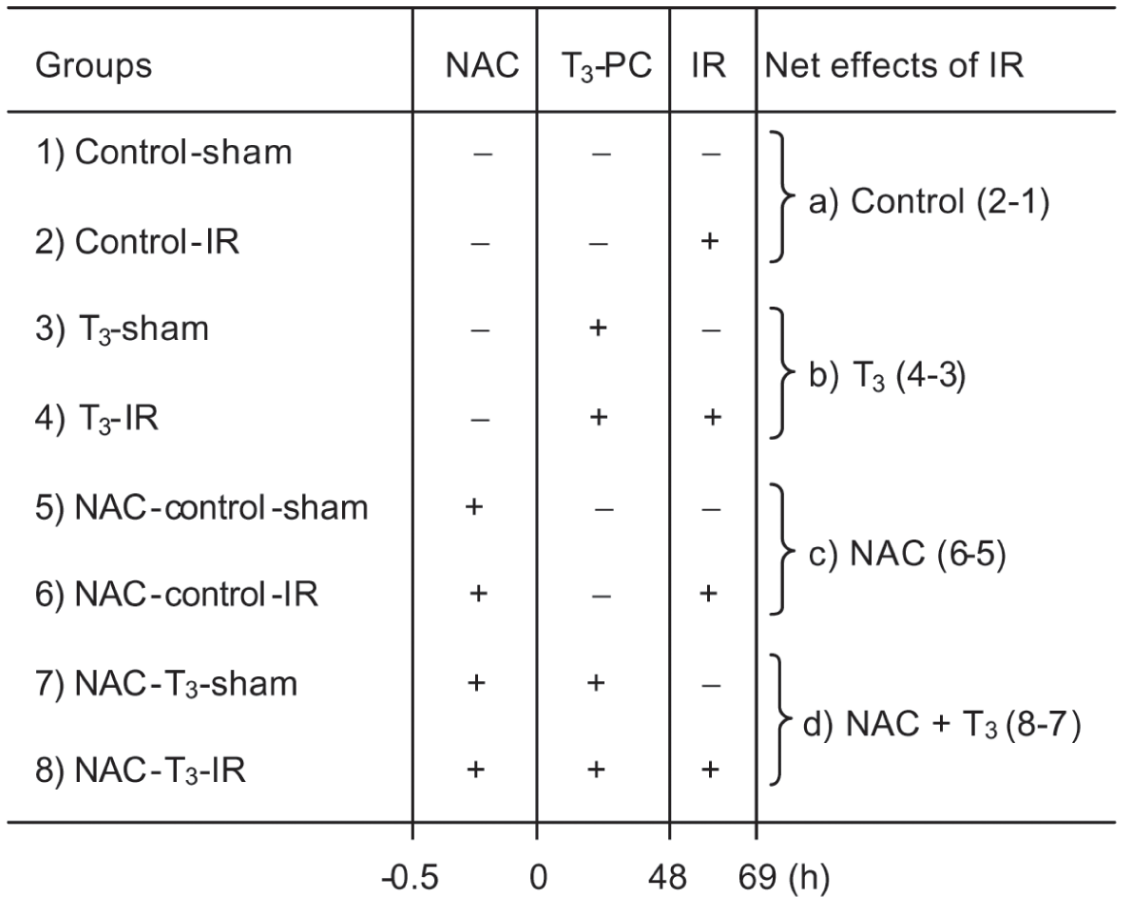

Figure 1: Experimental protocol to study the effects of $\mathrm{N}$-acetylcysteine (NAC) on liver iNOS mRNA expression in $\mathrm{T}_{3}$-induced preconditioning $\left(\mathrm{T}_{3}-\mathrm{PC}\right)$. Rats were given either $\mathrm{T}_{3}$ vehicle or a single dose of $\mathrm{T}_{3}(0.1 \mathrm{mg} / \mathrm{kg})$ at time zero. At $48 \mathrm{~h}$ after hormone treatment, groups of control and $\mathrm{T}_{3}$-treated animals were subjected to sham operation or to $1 \mathrm{~h}$ ischemia followed by $20 \mathrm{~h}$ reperfusion (IR). The effects of NAC were studied by subjecting the above-described groups to either saline $(0.9 \% \mathrm{NaCl})$ or NAC $(0.5 \mathrm{~g} / \mathrm{kg}) 0.5 \mathrm{~h}$ before $\mathrm{T}_{3}$, thus constituting eight experimental groups. Liver samples were obtained at the end of the experimental period of $69 \mathrm{~h}$ for iNOS mRNA and histological evaluation. Net changes induced by IR under conditions of no treatments (group (a) control), and after administration of $\mathrm{T}_{3}$ (group b), NAC (group c), or NAC $+\mathrm{T}_{3}$ (group d) shown in Fig. 3 were calculated by subtracting individual values of control-IR minus average control-sham $(2-1),(4-3),(6-5)$, and (8-7), respectively. 
mRNA, first-strand cDNA was synthesized from total RNA $(3 \mu \mathrm{g})$ using SuperScript RNAse H- Reverse Transcriptase (Invitrogen Corp., Carlsbad, CA, USA) and random hexamer primers [pd(N)6] (Promega, Madison, WI, USA). cDNA was amplified in a $P C R$ reaction using Taq DNA polymerase (Invitrogen Corp., Carlsbad, CA, USA) in the presence of primers specific for rat iNOS. Nucleotide sequences for sense and antisense primers used were 5,-CAACAACACAGGATGACC CTAA-3, and 5,-GGTAGGTTCCTGTTGT TTCTAT-3, (Invitrogen Corp., Carlsbad, CA, USA), respectively. In these conditions, a 417 bp sequence between +133 and +550 bp of rat iNOS cDNA was amplified. To control the relative amount of total mRNA transcribed in each reverse transcriptase reaction, an RNA $18 \mathrm{~S}$ invariant standard [Classic II 18S Internal Standards (324 bp); Ambion, The RNA Co., Austin, TX, USA] was used. PCR conditions included denaturation, annealing, and extension at 94, 56 , and $72^{\circ} \mathrm{C}$, for $30 \mathrm{~s}, 30 \mathrm{~s}$, and $60 \mathrm{~s}$, respectively, for 38 cycles. PCR products were electrophoresed on $2 \%$ agarose gels containing ethidium bromide, visualized by UV-induced fluorescence, and analyzed by densitometry using Scion Image (Scion Corp., Frederick, MD, USA) (Tapia et al., 2003).

\section{Statistical analyses}

Values shown are means \pm SEM for the number of separate experiments indicated. Net changes induced by IR under conditions of no treatment (group (a) control) and after administration of $\mathrm{T}_{3}$ (group b), NAC (group c), or NAC plus $\mathrm{T}_{3}$ (group d) were calculated by subtracting individual values of control-IR minus the average value of control-sham, $\mathrm{T}_{3}$-IR minus $\mathrm{T}_{3}$-sham, NAC-IR minus NAC-sham, or $\mathrm{NAC}_{-} \mathrm{T}_{3}$-IR minus NAC-T $\mathrm{T}_{3}$-sham, respectively (Fig. 1). One-way ANOVA and the Newman-Keuls test assessed the statistical significance of differences between mean values (GraphPad Prism ${ }^{\mathrm{TM}}$ version 2.0; GraphPad Software Inc., San Diego, CA, USA). A $p$ value of less than 0.05 was considered significant.

\section{RESULTS}

Representative agarose gel electrophoresis of RT-PCR products for iNOS mRNA (417 bp) and for $18 \mathrm{~S}$ rRNA (324 bp) after ethidium bromide staining in total hepatic RNA samples from groups of animals described in Fig. 1, are shown in Fig. 2A. Normalization of densitometric values of iNOS mRNA as iNOS mRNA/18S rRNA ratios showed $119 \%$ increase in hepatic iNOS expression in $\mathrm{T}_{3}$-treated animals subjected to IR compared to control-sham rats $(p<0.05)$ (Fig. 2B), with a net 7.7 -fold enhancement in the net effect of $\mathrm{T}_{3}$ over control values $(p<0.05)$ (Fig. 3A), calculated as shown in Fig. 1. In agreement a 12.7-fold increase in liver NOS activity of $\mathrm{T}_{3}$-IR rats, in relation to control-sham animals $(p<0.05)$ was found (Fig. 2C), with a net enhancement of 0.58 units in the net effect of $\mathrm{T}_{3}$ over control values $(p<0.05)$ (Fig. 3B). Both groups of rats subjected to IR alone or to $\mathrm{T}_{3}$ administration alone showed liver iNOS mRNA and NOS activity values comparable to those in control-sham animals (Fig. 2B and 2C). Pretreatment of rats with NAC, $0.5 \mathrm{~h}$ prior to $\mathrm{T}_{3}$ administration, abolished upregulation of iNOS expression and NOS activity in the liver of $\mathrm{T}_{3}$ - preconditioned rats subjected to IR when compared to the respective control-sham group or control animals without NAC pretreatment (Fig. 2B and $2 \mathrm{C}$ ), thus abrogating the net effect of $\mathrm{T}_{3}$ (Fig. 3A and 3B). Under the conditions used, NAC pretreatment alone did not significantly modify the hepatic expression of iNOS or the activity of liver NOS (Fig. $2 \mathrm{~A}$ and $2 \mathrm{~B}$ ).

Light microscopy studies of the liver revealed that control animals (group 1; see Fig. 1) and $\mathrm{T}_{3}$-treated rats (group 3) subjected to sham operation exhibited normal liver histology (Fig. 4A and 4C). In unpreconditioned animals, the IR protocol used elicited moderate congestion, with scattered cellular necrosis and sinusoidal neutrophil infiltration (group 2) (Fig. 4B), whereas $\mathrm{T}_{3}-\mathrm{PC}$ rats subjected to IR exhibited normal liver architecture with no apparent hepatic lesions (group 4) (Fig. 4D). In addition, animals pre-treated with 

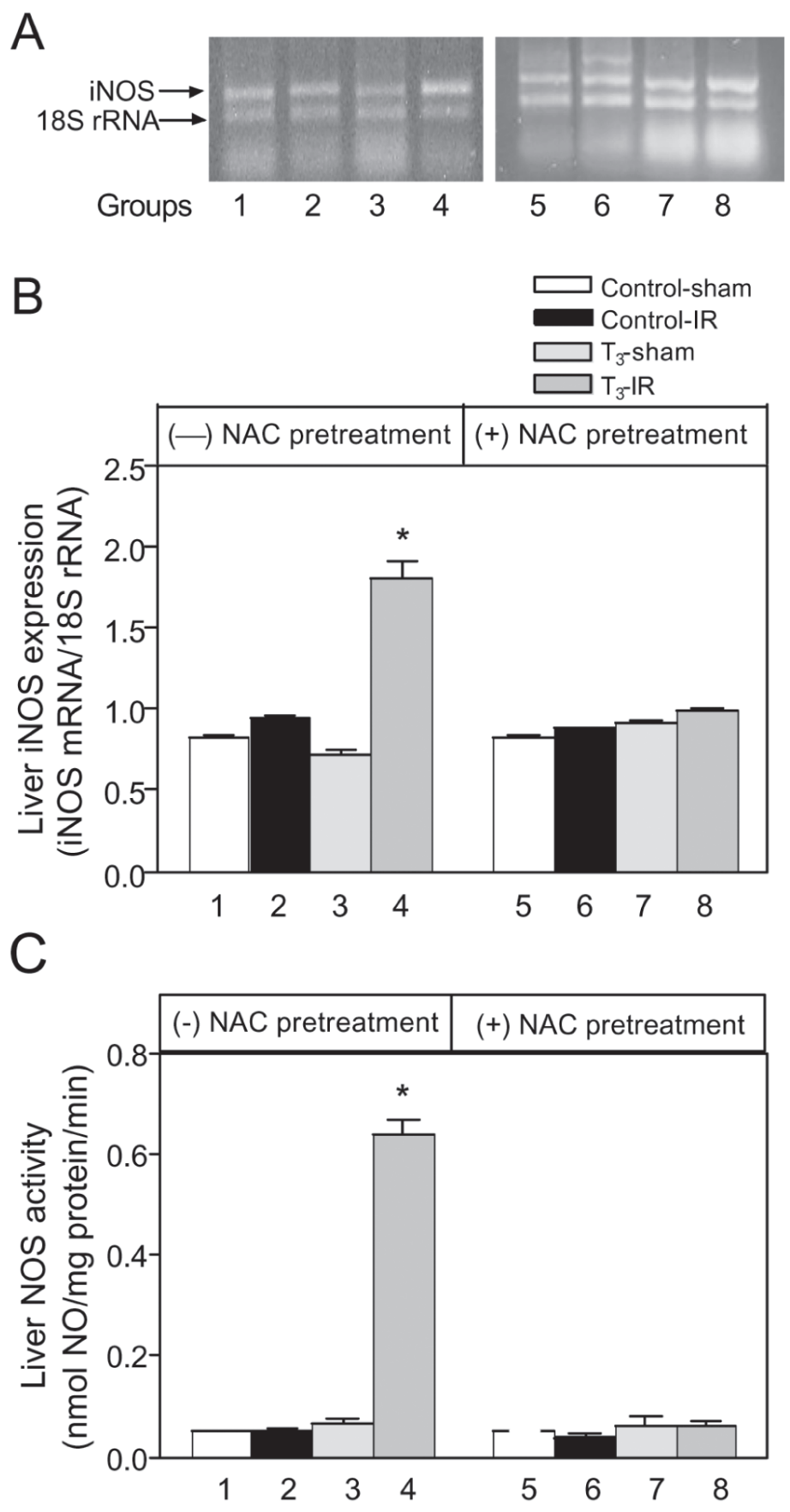

Figure 2: Effect of N-acetylcysteine (NAC) administration on the liver inducible nitric oxide synthase (iNOS) mRNA expression and nitric oxide activity after a hepatic ischemia-reperfusion (IR) protocol in unpreconditioned and $\mathrm{T}_{3}$-preconditioned rats. For this purpose, groups of animals were treated as shown in Fig. 1. (A) Representative agarose gel electrophoresis of the RT-PCR products for iNOS mRNA (417 bp) and for 18S rRNA (324 bp) after ethidium bromide staining in total hepatic RNA samples. (B) Densitometric quantification of RT-PCR products of iNOS mRNA expressed as iNOS mRNA/18S rRNA ratios to compare lane-lane equivalency in total RNA content. (C) Spectrophotometric assessment of nitric oxide activity. Each bar represents the mean \pm SEM for three to eleven animals per experimental group, identified by the numbers as shown in Fig. 1. Significance studies ${ }^{*} p<0.05$ compared to controls (groups 1 and 5) 
NAC prior to $\mathrm{T}_{3}$ administration and subjected to IR revealed extensive distortion of liver architecture, with necrosis in perivenular parenchyma, inflammation, and neutrophil infiltration (group 8) (Fig. 4E). NAC pretreatment did not alter liver histology outcome in controlsham (group 5), control-IR (group 6), and $\mathrm{T}_{3}$-sham (group 7) animals (data not shown), as compared to the respective groups of rats pre-treated with NAC vehicle (Fig. 4, A, B, and C).

\section{DISCUSSION}

IR liver injury is considered to underlie the development of a severe increase in the oxidative stress status (Droge, 2002; Jaeschke, 2003; Selzner et al., 2003; Gloire et al., 2006), whereas that related to PC strategies seems to be of a smaller magnitude (Casillas-Ramírez et al., 2006), as reported for $\mathrm{T}_{3}$-PC (Fernández et al., 2007a). Data presented in this work confirm earlier observations on the PC action of $\mathrm{T}_{3}$ as evidenced by significant prevention of liver injury induced by IR, which is related to suppression of the oxidative stress component and TNF- $\alpha$ response elicited by IR (Fernández et al., 2007a; 2008). Furthermore, the reported results indicate that $\mathrm{T}_{3}$-induced liver $\mathrm{PC}$ is associated with upregulation of iNOS expression and increased liver NOS activity. Significant enhancements in NO levels may constitute a defense mechanism affording hepatoprotective and anti-inflammatory effects (Laroux et al., 2000), which may be related to a negative feedback control by NO produced by the up-regulated iNOS to diminish excessive activation of $\mathrm{NF}-\kappa \mathrm{B}$ and transcription of its target genes during the IR protocol, thereby allowing the recovery

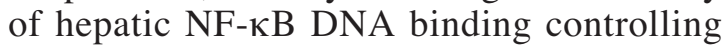
iNOS expression (Fernández et al., 2007a; 2008), which is lost after IR (Takahashi et al., 2001; Fernández et al., 2007a). The potential role of $\mathrm{NO}$ in inhibiting $\mathrm{NF}-\kappa \mathrm{B}$ activation and expression of proinflammatory genes during IR includes (i) ROS scavenging to decrease the prooxidant status oxidizing biomolecules and activating NF-kB (Takahashi et al., 2001); (ii) nitrosylation of NF-kB p50 that decreases NF-kB DNA binding (De la Torre et al., 1997); and/or (iii) induction and/or stabilization of IkB to inactivate NF-kB (Katsuyama et al., 1998). In addition, conditions leading to iNOS expression, which include $\mathrm{T}_{3}$ administration (Wong and Goeddel, 1988; Fernández et al., 1997; 2005a), also upregulate manganese superoxide dismutase (MnSOD) (Fernández et al., 2005b), thus sparing NO to maintain large $\mathrm{NO}$ levels required for negative feedback signaling (Janssen-Hininger et al., 2000).

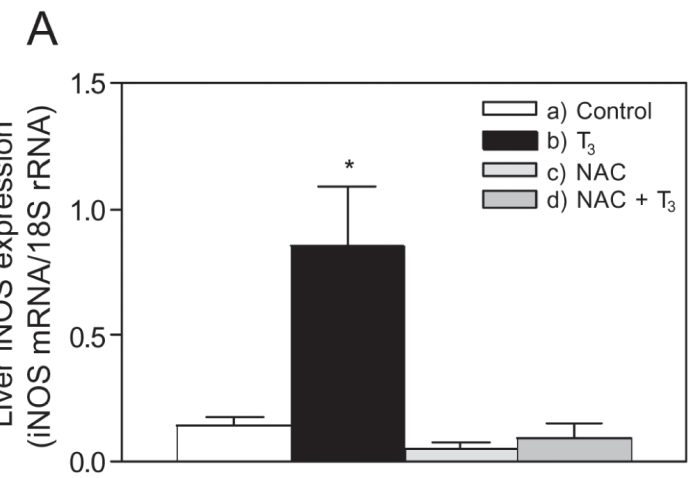

B

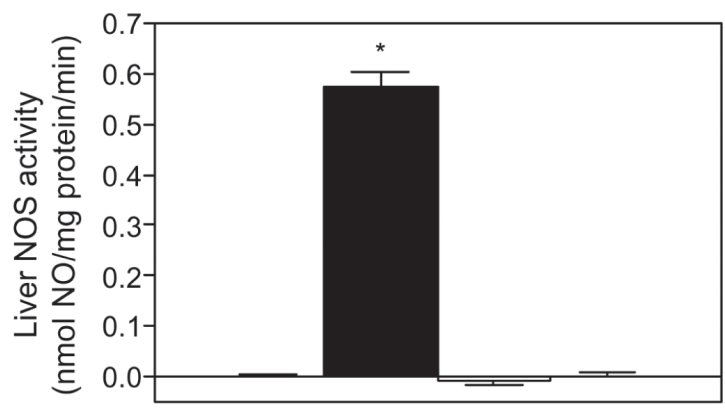

Figure 3: Net changes induced by ischemiareperfusion (IR) in liver inducible nitric oxide synthase (iNOS) mRNA expression and nitric oxide activity under conditions of no treatment (group (a) control) and after administration of $\mathrm{T}_{3}$ (group b), $\mathrm{N}$-acetylcysteine (NAC) (group c), or $\mathrm{NAC}+\mathrm{T}_{3}$ (group d). Net changes were calculated as described in Fig. 1. Values shown correspond to the means \pm SEM for three to eleven animals per group. Significance studies $* p<0.05$ compared to controls 
The causal role of $\mathrm{T}_{3}$-induced transient and reversible oxidative stress in liver PC against IR injury was established by the administration of NAC $0.5 \mathrm{~h}$ prior to $\mathrm{T}_{3}$. This protocol led to (i) significant serum levels of NAC that are not detectable at the end of the PC period of $48 \mathrm{~h}$ used, which assures its lack of interference with the oxidative stress response induced by IR; and (ii) suppression of both $\mathrm{T}_{3}$-dependent reduction in liver oxidative stress and PC induced by IR (Fernandez et al., 2008). In agreement with these findings, NACdependent abolishment of liver $\mathrm{T}_{3}$-PC was evidenced by the reestablishment of severe liver damage observed in the NAC-T 3 -IR group, which is comparable to that in the control-IR group. In concomitance, suppression of the iNOS expression and NOS activity upregulating effects of $\mathrm{T}_{3}$ in the $\mathrm{NAC}_{-} \mathrm{T}_{3}-\mathrm{IR}$ group, suggest that $\mathrm{T}_{3}-\mathrm{PC}$ is associated with oxidative stress-induced upregulation of iNOS expression and nitric oxide generation, which may function as a protective mechanisms against IR injury. Upon administration, NAC is readily deacetylated in cells to produce L-cysteine required for reduced glutathione (GSH) synthesis de novo (De Flora et al., 2001), the major water-soluble antioxidant of the liver (Kaplowitz et al., 1985). Also, NAC per se can function as a direct free-radical scavenger compound and as a specific substrate for glutathione peroxidase and glutathione-S-transferases catalyzing the removal of oxidative stress-derived peroxides and electrophiles (Kaplowitz et al., 1985; De Flora et al., 2001). Although these actions of NAC may explain the suppression of oxidative stress-dependent hepatic iNOS upregulation, NOS activity enhancement and liver injury in $\mathrm{T}_{3}-\mathrm{PC}$, other mechanisms can be involved, including the inhibition of the expression of
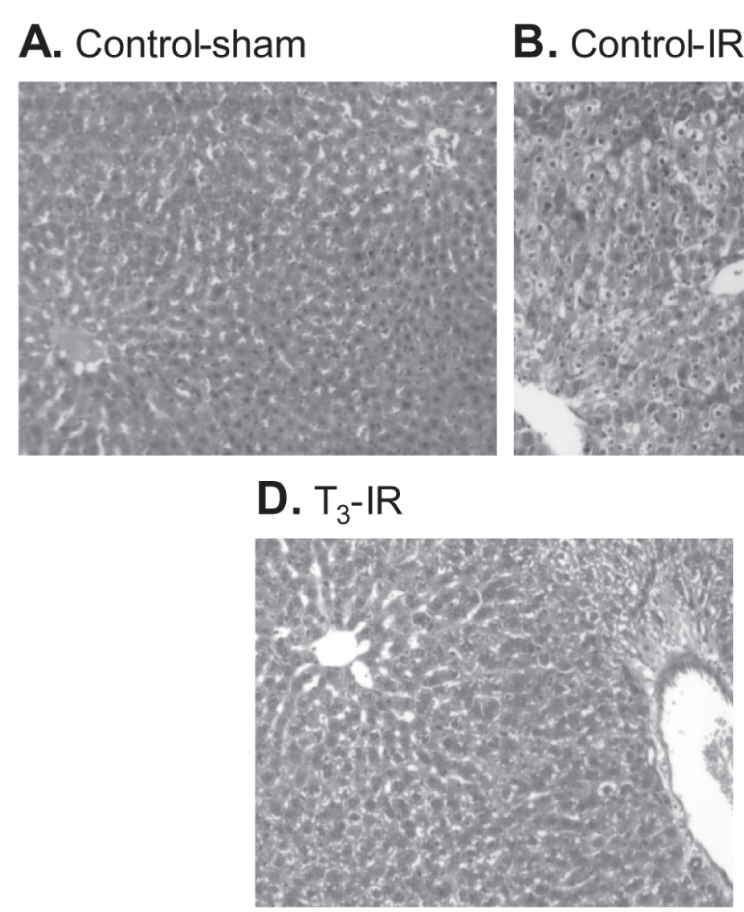

B. Control-IR

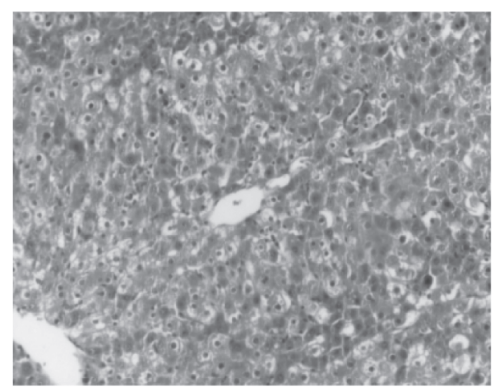

E. NAC-T $-\mathrm{IR}$
C. $T_{3}$-sham

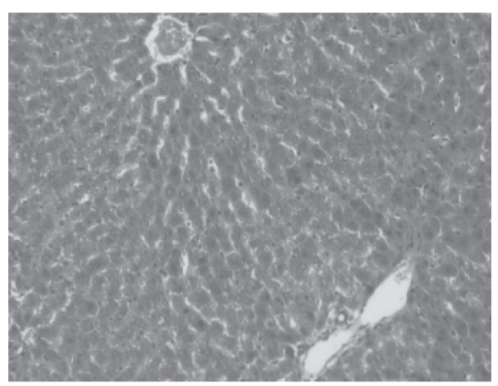

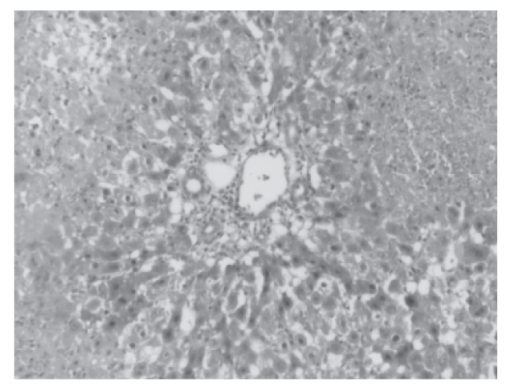

Figure 4: Liver histology after hepatic ischemia-reperfusion (IR) in unpreconditioned, $\mathrm{T}_{3^{-}}$ preconditioned rats, and $\mathrm{T}_{3}$-preconditioned animals subjected to $\mathrm{N}$-acetylcysteine (NAC) administration prior to $\mathrm{T}_{3}$, as shown in Fig. 1. (A) A control-sham operated rat, (B) a control animal subjected to $1 \mathrm{~h}$ ischemia followed by $20 \mathrm{~h}$ reperfusion, (C) a $\mathrm{T}_{3}$-treated sham-operated rat, (D) a $\mathrm{T}_{3}$-treated animal subjected to IR, and (E) a NAC-pretreated $\mathrm{T}_{3}$-treated rat subjected to IR (hematoxylin-eosin-stained liver sections from a total of three to four animals per group; original magnification $\mathrm{x} 10)$. 
IKK, NF-KB-inducing kinase (NIK) (Ho et al., 1999), and NF-KB nuclear translocation by NAC (Weber et al., 1994; Oka et al., 2000). However, these aspects remain to be studied in $\mathrm{T}_{3}$-induced liver PC.

In conclusion, data reported indicate that $\mathrm{T}_{3}$-induced liver $\mathrm{PC}$ is associated with upregulation of iNOS and NOS activity as a protective mechanism against IR injury. This is achieved through the development of transient and reversible oxidative stress, being related to the recovery of liver cell signaling functions such as the DNA binding capacity of $\mathrm{NF}-\kappa \mathrm{B}$ controlling iNOS expression, which is lost during IR (Fernandez et al., 2007a). In agreement with this contention, enhancement in oxidative stress status and NF-kB activation in lymphocytes from hyperthyroid patients are associated with the increase in serum immunoglobulin levels, strengthening the positive influence of thyroid hormones on the immune system (Nandakumar et al., 2008). In addition to iNOS, NF- $\kappa \mathrm{B}$ upregulates the expression of numerous genes associated with hepatoprotection, namely, MnSOD, Bcl-2 (Fernández et al., $2005 \mathrm{~b}$ ), and the acute-phase proteins type I (Tapia et al., 2006) after $\mathrm{T}_{3}$ administration, whereas recovery of the DNA binding capacity of STAT3 in $\mathrm{T}_{3}$-PC may also contribute to protection by triggering the expression of acute-phase proteins and hepatocyte proliferation (Tapia et al., 2006; Fernandez et al., 2007b). The involvement of these mechanisms in $\mathrm{T}_{3}$ liver $\mathrm{PC}$ is currently under study in our laboratory.

\section{ACKNOWLEDGEMENTS}

This work was supported by grant 1080039 from FONDECYT, Santiago, Chile.

\section{REFERENCES}

CASILLAS-RAMÍREZ A, MOSBAH IB, RAMALHO F, ROSELLÓ-CATAFAU J, PERALTA C (2006) Past and future approaches to ischemia-reperfusion lesion associated with liver transplantation. Life Sci. 79: 1881-1894

CHOMCZYNSKI P, SACCHI N (1987) Single-step method of RNA isolation by acid guanidinium thiocyanate- phenol-chloroform extraction. Anal. Biochem. 162: 156-159

DAVIS PJ, LEONARD JL, DAVIS FB (2008) Mechanisms of nongenomic actions of thyroid hormone. Front. Neuroendocrinol. 29: 211-218

DE FLORA S, IZZOTTI A, D'AGOSTINI F, BALANSKY RM (2001) Mechanisms of $\mathrm{N}$-acetylcysteine in the prevention of DNA damage and cancer, with special reference to smoking-related end-points. Carcinogenesis 22: 999-1013

DE LA TORRE A, SCHROEDER RA, KUO PC (1997) Alteration of NF- $\kappa \mathrm{B}$ p50 DNA binding kinetics by Snitrosylation. Biochem. Biophys. Res. Commun. 238: 703-706

DRÖGE W (2002) Free radicals in the physiological control of cell function. Physiol. Rev. 82: 47-95

FERNÁNDEZ V, CORNEJO P, TAPIA G, VIDELA LA (1997) Influence of hyperthyroidism on the activity of liver nitric oxide synthase in the rat. Nitric Oxide 6: 463-468

FERNÁNDEZ V, TAPIA G, VARELA P, VIDELA LA (2005a) Redox regulation of thyroid hormone-induced Kupffer cell-dependent IkB-a phosphorylation in relation to inducible nitric oxide synthase expression. Free Radic. Res. 39: 411-418

FERNÁNDEZ V, TAPIA G, VARELA P, CASTILLO I, MORA C, MOYA F, ORELLANA M, VIDELA LA (2005b) Redox up-regulated expression of rat liver manganese superoxide dismutase and $\mathrm{Bcl}-2$ by thyroid hormone is associated with inhibitor of $\mathrm{kB}-\alpha$ phosphorylation and nuclear factor $\mathrm{kB}$ activation. $\mathrm{J}$. Endocrinol. 186: 539-547

FERNÁNDEZ V, CASTILLO I, TAPIA G, ROMANQUE P, URIBE-ECHEVARRÍA S, URIBE M, CARTIERUGARTE D, SANTANDER G, VIAL MT, VIDELA LA (2007a) Thyroid hormone preconditioning: protection against ischemia-reperfusion liver injury in the rat. Hepatology 45: 170-177

FERNÁNDEZ V, REYES S, BRAVO S, SEPÚLVEDA R, ROMANQUE P, SANTANDER G, CASTILLO I, VARELA P, TAPIA G, VIDELA LA (2007b) Involvement of Kupffer cell-dependent signaling in $\mathrm{T}_{3}$ induced hepatocyte proliferation in vivo, Biol. Chem. 388: $831-837$

FERNÁNDEZ V, TAPIA G, VARELA P, GAETE L, VERA G, MORA C, VIAL MT, VIDELA LA (2008) Causal role of oxidative stress in liver preconditioning by thyroid hormone in rats, Free Radic. Biol. Med. 44: 1724-1731

GLOIRE G, LEGRAND-POELS S, PIETTE J (2006) NF$\mathrm{kB}$ activation by reactive oxygen species: fifteen years later. Biochem. Pharmacol. 72: 1493-1505

HO E, CHEN G, BRAY TM (1999) Supplementation of Nacetylcysteine inhibits NFkB activation and protects against alloxan-induced diabetes in CD-1 mice. FASEB J. 13: $1845-1854$

JAESCHKE H (2003) Molecular mechanisms of hepatic ischemia-reperfusion injury and preconditioning. Am. J. Physiol. Gastrointest. Liver Physiol. 284: G15-G26

JANSSEN-HEININGER YMW, POYNTER ME, BAEUERLE PA (2000) Recent advances towards understanding redox mechanisms in the activation of nuclear factor kB, Free Radic. Biol. Med. 28: 13171327

JANSSEN-HEININGER YMW, BOSSMAN BT, HEINTZ NH, FORMAN HJ, KALYANARAMAN B, FINKEL T, STAMLER JS, RHEE SG, VAN DER VLIET A (2008) Redox-based regulation of signal transduction: principles, pitfalls, and promises, Free Radic. Biol. Med. 45: 1-17 
KAPLOWITZ N, AW TY, OOKHTENS M (1985) The regulation of hepatic glutathione, Ann. Rev. Pharmacol. Toxicol. 25: 715-744

KATSUYAMA K, SHICHIRI M, MARUMO F, HIRATA Y (1998) NO inhibits cytokine-induced iNOS expression and NF- $\kappa \mathrm{B}$ activation by interfering with phosphorylation and degradation of IkB. Arterioscler. Thromb. Vasc. Biol. 18: 1796-1802

KNOWLES RG, MERRET M, SALTER M, MONCADA S (1990) Differential induction of brain, lung, and liver nitric oxide synthase by endotoxin in the rat. Biochem. J. 270: 833-836

LAROUX FS, LEFER DJ, KAWACHI S, SCALIA R, COCKRELL AS, GRAY L, VAN DER HEYDE H, HOFFMAN JM, GRISHAM MB (2000) Role of nitric oxide in the regulation of acute and chronic inflammation. Antiox. Redox Signal. 2: 391-496

LOWRY OH, ROSEBROUGH NJ, FARR AL, RANDALL RJ (1951) Protein measurement with the Folin phenol reagent. J. Biol. Chem. 193: 265-275

NANDAKUMAR DN, KONER BC, VINAYAGAMOORTHI R, NANDA N, NEGRI VS, GOSWAMI K, BOBBY Z, HAMIDE A (2008) Activation of NF- $\mathrm{KB}$ in lymphocytes and increase in serum immunoglobulin in hyperthyroidism: possible role of oxidative stress. Immunobiology 213: 409-415

OKA S, KAMATA H, KAMATA K, YAGISAWA $\mathrm{H}$, HIRATA H (2000) N-Acetylcysteine suppresses TNFinduced NF- $\kappa B$ activation through inhibition of IkB kinases. FEBS Lett. 472: 196-202

SELZNER N, RUDIGER H, GRAF R, CLAVIEN PA (2003) Protective strategies against ischemic injury of the liver, Gastroenterology 125: 917-936

TAKAHASHI Y, GANSTER RW, GAMBOTTO A, SHAO L, KAIZU T, WU T, YAGNIK GP, NAKAO A, TSOULFAS G, ISHIKAWA T, OKUDA T, GELLER
DA, MURASE N (2001) Role of NF-KB on liver cold ischemia-reperfusion injury. Am. J. Physiol. Gastrointest. Liver Physiol. 283: G1175-G1184

TAPIA G, FERNÁNDEZ V, VARELA P, CORNEJO P, GUERRERO J, VIDELA LA (2003) Thyroid hormoneinduced oxidative stress triggers nuclear factor-kB activation and cytokine gene expression in rat liver. Free Radic. Biol. Med. 35: 257-265

TAPIA G, FERNÁNDEZ V, PINO C, ARDILES R, VIDELA LA (2006) The acute-phase response of the liver in relation to thyroid hormone-induced redox signaling, Free Radic. Biol. Med. 40: 1628-1635

TSUKAMOTO H, LIN M (1997) The role of Kupffer cells in liver injury. In: E. WISSE, D.L. KNOOK, C. BALABAUD (eds.) Cells of the Hepatic Sinusoid, The Kupffer Cell Foundation, Leiden, The Netherlands, 6: 244-250

VARELA P, TAPIA G, FERNANDEZ V, VIDELA LA (2006) The role of thyroid hormone calorigenesis in the redox regulation of gene expression. Biol Res; 39: 611617

VIDELA LA. FERNÁNDEZ V, TAPIA G, VARELA P (2007) Thyroid hormone calorigenesis and mitochondrial redox signaling: upregulation of gene expression. Front. Biosci. 12: 1220-1228

WEBER C, ERL W, PIETSCH A, STROBEL M, ZIEGLER-HEIBROCK H，WEBER PC (1994) Antioxidants inhibit monocyte adhesion by suppressing nuclear factor kappa-B mobilization and induction of vascular adhesion molecule-1 in endothelial cells stimulated to produce radicals. Atheroscl. Throm. 14: 1665-1673

WONG GH, GOEDDEL DV (1988) Induction of manganese superoxide dismutase by tumor necrosis factor: possible protective mechanism. Science 242: 941-944 
